\title{
THE LANDSLIDE DISTRIBUTION IN LOANO SUB-DISTRICT, PURWOREJO DISTRICT, CENTRAL JAVA PROVINCE, INDONESIA
}

\author{
Junun Sartohadi \\ Department of Environmental Geography \\ Faculty of Geography \\ Gadjah Mada University \\ Yogyakarta, Indonesia \\ E-mail: panyidiksiti@yahoo.com
}

\begin{abstract}
Ohis research was proposed to figure out the importance of human influence on landslide disaster. The research objectives were: (1) to map the locations of landslide during the period of January 2004 - March 2008 of the study area; (2) to map the degree of landslide hazard of the study area; (3) to analyze the distribution of landslide based on the landslide hazard map; and (4) to analyze the distribution of landslide based on the road network. The method of this research consists of field survey and laboratory works. The field survey was intended to map the location of landslide which bappened during the period of January 2004 up to March 2008. The land characteristics and land qualities data have been collected based on geomorphological approach. The laboratory works were proposed to analyze the field data of land characteristics and land qualities for landslide hazards classification and mapping purposes. Scoring method was applied for landslide hazard evaluation. Some geographical information techniques were applied for mapping purposes and spatial data analysis of landslide distribution. Map overlay and buffering techniques were applied during landslide distribution analysis. The results of the research showed that: (1) there were 291 landslides collected during the research period; (2) the study area consists of very high, high, moderate, and low of landslide hazard classes. There was no safe area of landslide hazard within the study area; (3) most the landslide occasions were more influenced by buman activities than derived by physical conditions. Some of human activities that induced landslide in the study area were slope cutting for: road construction, houses, agricultural purposes, and sand and stone mining in the river canal; (4) the spatial distribution of most landslide (>90\%) were parallel with road networks.
\end{abstract}

Keywords: landslide, hazard, spatial distribution, geomorphological approach

\section{INTRODUCTION}

Indonesia is the country with the second highest number of landslides in the world after China (ILC, 2004). Specifically, the landslide occasions in Java Island within 16 years, since 1990 up to 2006, were more than 1000 occasions with average 62 occasions annually (Hadmoko 2007, Hadmoko and Lavigne 2007, Marfai et al 2007). The highest number of landslide in Indonesia is due to topographical condition in combi- nation with rainfall. The topographic situation may vary from gently to very steep. The rainfall is usually more than $2000 \mathrm{~mm} /$ year. The high population growth creates some new settlement areas located in the hilly area. Based on the previous statement, the landslide hazard in Indonesia tends to generate casualty, material losses and damage.

Purworejo District is one of the regencies in Central Java Province which is 
vulnerable to landslide hazard. Purworejo District is located at $109.78^{\circ} \mathrm{E}, 7,91^{\circ} \mathrm{S}$ to $110.15^{\circ} \mathrm{E}, 7,51^{\circ} \mathrm{S}$. The collected data from institutional surveys and fieldworks since January 2004 up to March 2008 showed that there were 316 landslides. All the landslides dispersed in the hilly and mountainous areas. The hilly and mountainous area dominated $40 \%$ of the district. The high number of landslide occasions happened in 2004, which happened in the two extreme rainfall intensity $(>70 \mathrm{~mm} /$ hour $)$ in the January $29^{\text {th }} 2004$ and December $27^{\text {th }}$ 2004.

The Loano Sub-district is one of the very vulnerable areas of landslide hazard in Purworejo District. Figure 1 shows Purworejo District and the Loano Sub-district as the study area. Among 320 of the landslide occasions in the year 2004 up to 2008, there were more than 290 landslides $(>90 \%)$ with various size found in the Loano Sub-district. The landslide occasions in the Loano Sub-district mostly happened during 2004, subsequent with the high extreme precipitation which happened generally in Purworejo District.

The landslides in Loano Sub-district provoked casualty and material losses and damage. The casualty happened if the landslide took place near to settlement area and or in the settlement area. The material losses and damages occured when the landslide happened in the settlement area or public facilities, such as road. When the landslide took place in the road, the village or the subvillage will be inaccessible. This will affect the relief and the aid distribution program in order to minimize the victims.

The field observations during more than 3 years research period had figured out that the study area was located in the landslide prone area. The landslide happened in all parts of the study area both in the rolling, hilly, and mountainous areas. Quick observation of the landslide distribution showed that most of the landslides were located nearby the road. Based on all of the mentioned situations, the research problems were formulated as follow:

1. How are the spatial distribution of the landslides during period of January 2004-March 2008?

2. How is the vulnerability and hazard map of the landslides in the study area?

3. Are the landslides in the study area always located in the high vulnerable area?

4. Is the road network in the study area traversing the high vulnerable area of landslide?

Based on the research problems formulation, the objectives of this research were formulated below:

1. to map the landslide during the study period of January 2004 - March 2008

2. to prepare landslide hazard map of the study area based on the evaluation of physical conditions presented in the 1 : 25.000 scale of base map

3. to analyze the distribution of landslide based on the landslide hazard map

4. to analyze the distribution of landslide based on the road networks

Landslide is a gravitational process working on every material located in the sloping areas. Since the landslide is considered as gravitational process, the physical principle is able to explain the landslide process. 


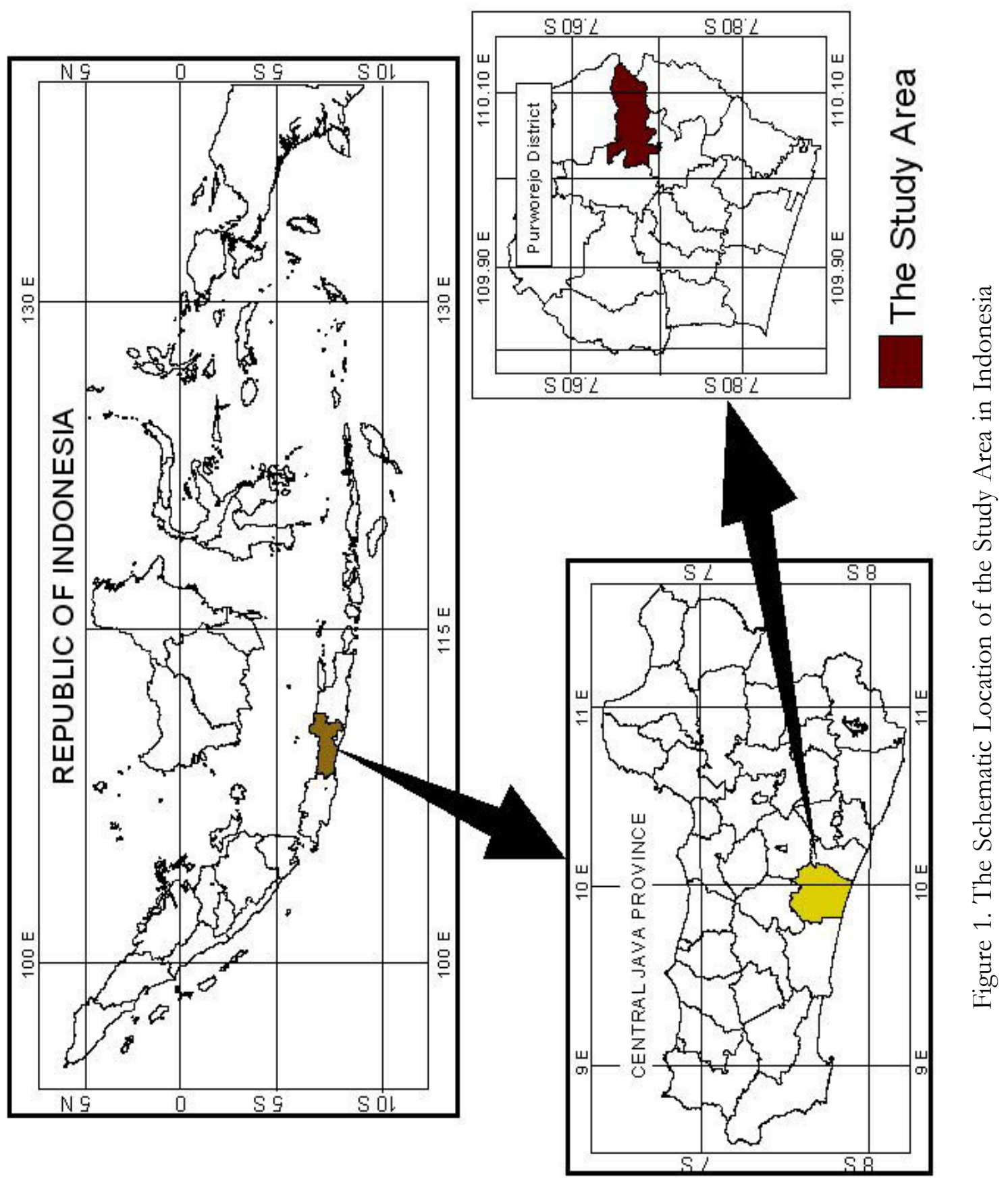


$\mathrm{Ep}=\mathrm{m} \cdot \mathrm{g} \cdot \mathrm{h}($ Kuhn, 1996)

Ep : the potential energy

$\mathrm{m}$ : mass weight

$\mathrm{g}$ : the acceleration of gravity

$\mathrm{h}$ : the height difference

According to physical principle above, some statements are formulated below:

a) mass weight of the landslide material consists of soil, rock, biomass, and man-made building. The heavier the mass weight, the higher potential energy which cause landslide.

b) all of the materials located in the certain elevation will be affected by gravitational force. The force of gravity of all material on all the Earth's surface is relatively constant, which is $9.8 \mathrm{~m} / \mathrm{s}^{2}$.

c) the elevation difference can be defined as the different between the initial position of material and the end position of landslide materials deposited. The line linking those two points is defined as slope. The larger the slope, the greater the potential energy which caused landslide.

Mass weight is a factor which is dynamic in nature and can be influenced by the natural as well as artificial environmental changing. The natural changing is the variation of humidity in the dry and the rainy season. The artificial environmental change is caused by land use and land management. Generally, landslide happens during the rainy season.

Mass weight changes, which caused landslide, are controlled by several factors, such as the soil thickness, soil structure, soil texture, degree of weathering process, weathered soil thickness, rock type and rock structure. The rock and soil characteristics are determining the amount of water content in it. The larger the capacity to absorb water, the larger the potency of mass weight change (Schaetzl and Anderson, 2005).

The type of human activities potentially induced change of mass weight and slope inclination. The terrace construction for agricultural land and or settlement development also potentially contributes to the changes of mass weight. The terrace construction may introduce more infiltration water both in the soil and in the rock formations. Meanwhile, changes of slope inclination occurred due to the slope cutting for road network or terrace application. The development of fish pond or other infrastructure developments to control overland flow also increase the mass weight. High density plantation of perennial crop which is not the indigenous types of local plantation may also articulate as the additional mass weight (Cornforth, 2004).

\section{THE RESEARCH METHODS}

\section{Landslide distribution mapping}

Cencus method has been applied to map the landslide. All landslides were identified using the Global Positioning System (GPS). All points with GPS positions were plotted into the $1: 25.000$ scale of base map. Landslides mapped in this study were the landslide which happened during the period January 2004 - March 2008. The data collection was started from January 2004 as the research cooperation between the Department of Physical Geography and the local government of the Purworejo 
District was initiated. This report was made after the end of the rainy season of the year 2008, that was in March.

\section{Landslide hazard mapping}

Geomorphological approach has been applied widely for hazard and environmental impact assessment, including landslide hazard mapping (Alkema and Cavallin 2001). Research pertaining to landslide assessment using geomorphological approach has been done by researchers in the world, as examples Marfai (2007), Moeyesons (2004), Korup (2003), Van Westen et al (2003), Dai et al (2002), Moon and Simpson (2002), Shuzui (2001), and Slymaker and Spencer (1998). In this study, landslide hazard mapping was based on the geomorphological approach with landform as the analysis unit. The evaluation of landslide hazard was based on the land characteristics and land quality analysis. The land characteristics applied in the landslide hazard mapping covered slope inclination, soil characteristics, rock characteristics, and land use types. The landslide hazard evaluation was based on scoring method (Table 1).
The land characteristics were classified into five categories. The highest score, 5 , means the strongest contribution to the landslide. The lowest score, 1 , means the least contribution to landslide. Weighing was formulated based on the understanding towards the influence factor and triggering factor of landslide. The gravitational force which acts upon soil mass or rocks was the strongest influence factor of landslide. In the field, it is easily define as the slope inclination. Thus, to assess the landslide hazard status, the slope factor was considered as the utmost weight compared to other factors.

The triggering factor was categorized into twofold, first the static factor, and second, the dynamic factor. Higher weight was given to dynamic factor because the landslide occurrence always triggered by the changes on the potential energy which dynamic in nature. The rainfall factor and land use were included in this dynamic factors. The weight given to rainfall was higher compared to land use because it gave abruptly clear impact to the weight of soil mass and or rock mass compared to land use. The

Table 1. Land quality and characteristic for landslide

\begin{tabular}{|c|l|l|}
\hline No & \multicolumn{1}{|c|}{ Land quality } & \multicolumn{1}{c|}{ Land characteristics } \\
\hline 1 & Topography & Slope angle \\
\hline 2 & Lithology & Type of rock \\
\hline 3 & \multirow{2}{*}{ Soils } & Soil thickness \\
\cline { 3 - 3 } & & Soil permeability \\
\cline { 3 - 3 } & & Soil texture \\
\hline 4 & Climate & Rainfall \\
\hline 5 & Land use & Land use type \\
\hline
\end{tabular}

Source: Gunadi, et al., 2004. 
dynamic factors also included the earthquake factor as a triggering factor to landslide. Since the study area was relatively small, it was assumed to have similar chance towards earthquake. Hence, the earthquake factor was not included in the evaluation of landslide hazard.

The groundwater condition plays role on the landsliding processes. The changes of groundwater was controlled by the infiltration rate of the soil and rock layers above the phreatic surface of groundwater, the occurrence of rainfall water, and the landuse types such as fish pound and paddy field with terraces. The infiltration rate was influenced by the properties of soil and rock layers which had been evaluated as separate factors as well as landuse types. Therefore, in order to avoid double evaluation the groundwater condition was not evaluated separately in the landslide hazard mapping processes.

Static factor was divided into twofold, soil and rock. Rock was weighted higher than the soil because rock was underlaying of soil layer. Changes occurs to- wards bed rock will instantly affect the soil stability overlying on it. Meanwhile, any changes occurs within the soil was not correspond directly towards the underlying bed rock. Detailed weighing techniques were given in the following Table 2 .

\section{Distribution of landslide and landslide hazard}

The landslide, which already mapped in to the base map was hence being descriptively analyzed to study the distribution using landslide hazard map and road network. Map overlay techniques were applied to analyze the distribution of landslide based on areas of landslide hazard classes. Buffering techniques were applied to analyze the distribution landslide based on road network. In the analysis of landslide distribution based on the road network, 100 meter buffering technique was applied. That distance was mainly considering the 1 : 25.000 scale of base map used in the research. Therefore, 100 meter in the field is equal to $4 \mathrm{~mm}$ in the map. In facts, the field observations of the landslide located less than $100 \mathrm{~m}$ distance from the road was induced by the road constructions.

Table 2. Weighing Parameters for Landslide Hazard Mapping

Source: Gunadi, et al., 2004. 
Table 3. Landslide Hazard Classification

\begin{tabular}{|c|l|c|}
\hline No & Degree of Landslide Hazard & Total Score \\
\hline 1 & Very low & $24-43,2$ \\
\hline 2 & Low & $>43,2-62,4$ \\
\hline 3 & Moderate & $>62,4-81,6$ \\
\hline 4 & High & $>81,6-100,8$ \\
\hline 5 & Very High & $>100,8-120$ \\
\hline
\end{tabular}

Source: Gunadi, et al., 2004.

\section{RESULTS AND DISCUSSIONS}

The geomorphology and the general descriptions of the study area

Morphologically, the study area is situated in the hilly to mountainous landscape with narrow inter-hills and intermountainous valleys. Started from the main road that connecting Purworejo city to Magelang, the elevation of the study area is gradually increased to both directions of west and east in the form as mountainous areas. The hilly part of the study areas were formed of tuffaceous sandstone in the western part and breccias hill in the middle to the east. The tuffaceous sandstone hills were covered by volcanic material from Sumbing Volcano. The breccias hills were interrupted by andesitic lava and limestone hills in the top of the eastern mountainous area.

Stratigraphically, the study area was formed from the oldest rock such as tuffaceous sandstone which overlaid with andesite-dacite breccia and limestone. The formations of those rocks were uplifted and at the same time it was interrupted by andesite lava, thus it is seen as the recent morphology. The highest elevation of the mountainous area is covered by limestone and it is only occupy a small portion of the mountainous area.

Faulting and joint process also occurred during the uplifting process. Across the joint and fault line there were exogenous process such as weathering, erosion, masswasting and sedimentation forming a stream channel order 1 to 4 . The dominant process along the stream was should be valley deepening and valley lengthening. Since the river bed was consists of hard rock, thus the widening process and meandering process become more intensive.

The characteristics of landform in the study area can be summarized in the Table 4. The andesitic breccias mountain and hills are located in the eastern side, while the tuffaceous sandstone hills are located in the western side. The alluvium plain is located along the river. Those 5 main landform was delineated more detail based on the contour pattern analysis and their morphoarrangement to perform detail landform units. Based on the landform units the land characteristics and land quality were evaluated to generate information about landslide hazard class. Therefore, the delineation unit of the landslide hazard map presented in the Figure 2 was based on the landform unit delineation. 
Table 4. The Landform Characteristic of the Study Area.

\begin{tabular}{|l|l|l|l|l|c|}
\hline $\mathrm{Nr}$ & \multicolumn{1}{|c|}{ Morphology } & Main Rocks Formation & Structure & \multicolumn{1}{|c|}{ Genesis } & $\begin{array}{c}\text { Acreage } \\
(\mathrm{Ha})\end{array}$ \\
\hline 1 & Undulating Plain & Alluvium & Horizontal & Fluvial & 1766.0 \\
\hline 2 & Hills & Andesitic Breccias & Massive & Tertiary-Volcanic & 898.0 \\
\hline 3 & Mountain & $\begin{array}{l}\text { Andesitic Breccias } \\
\text { Andesitic Intrusion }\end{array}$ & Massive & Tertiary-Volcanic & 2035.6 \\
\hline 4 & Hills & Tuffaceous Sandstone & Massive & Tertiary-Volcanic & 520,0 \\
\hline 5 & Mountain & Limestone & Massive & Solutional & 41.0 \\
\hline
\end{tabular}

Source: map analysis

Climatic condition in the study area was tropical wet climate, with annual precipitation more than $2900 \mathrm{~mm}, 8$ wet months during the year. Extreme monthly rainfall $(>300 \mathrm{~mm} / \mathrm{month})$ is in December-March. The existing climate condition, the geomorphological factors and the land use were affecting the study area to have high landslide hazard.

The topography of study area was highly induced by human activities. In the initial regional development, the settlement was only occupied the plain areas. In the further development, the break of slope zones between the middle slope and upper slope also settled by the inhabitant. Many new settlements occupied the break slope zone since the availability of springs which can be fulfilling the need of domestic water around this area. The rest area was utilized for agricultural activities with the terraces practice. The human induced activities which appear as landuse type within the study area and its relation with the landslides distribution were presented in Table 5. The highest density of landslide occurs in the settlement area.

The road network in the study area consists of national, provincial, and local road. The national road is the largest road and it divides the study area into two parts, west and east parts. The national road that connecting Purworejo and Magelang has two branches: to the west direction to KepilWonosobo, and to the east direction to Banyuasin Separe the capital city of the Loano Sub-district. The local road has many branches that connecting villages to the capital city of the Loano Sub-district.

Since year of 90's, had been initiated a program dealing with the road improvement from narrow trail into road that can be passed by four wheels vehicle. Many roads were widened and stiffened with the river stones in order to open the isolated settlement. The road improvement process was carried out by cut and fill of land across the slopes. Those activities continued until this moment in form of asphalting, hence the big vehicles (trucks) intensity is getting higher in the village's road. The traffic which transports heavy material such as timbers or building materials had vibrated the land surround the road and has triggered the landslide process.

Natural resources exploitation has decreased the carrying capacity of the study 
Table 5. Landuse Type and Landslide Distribution

Source: map analysis

area. One of the natural resource exploitation is the form of building materials (sand and stone) mining. The sand and stone mining activities along the river had been getting more intensive in accordance with the road construction in order to open the isolated area (Ritohardoyo, 2005). The deposition rate along the river has not balanced with sand and stone removal. Finally, the mining activities along the rixer had deep-

Landuse Type

Mixed garden time the strealph R. J directly reached the bed Settlement rock, i.e. vołsenge breccia and 65 andesite Paddy field lava flow. This 12 valley deepening process Dry land farm stream could 37 hot erode the begrock anyTotal more, as a c5200.quence riverbathy 1 erosion becomes more intensive. Those two situations, valley deepening and river bank erosion were becoming trigger factor controlled the landslide along the river bank. Schematic situation of the footslope - river bank landslide processed is presented in Figure 2. On that figures the vegetation situation have not been presented since there were no significant landuse changes.

\section{Landslide Hazard of the Study Area}

Based on the geomorphological approach and landslide hazard evaluation by scoring method, the study area consist of four classes of hazard, i.e.,: low, moderate, high, and very high. The scoring was made base on land characteristics evaluation measured in every landform unit. The distribution of landslide hazard areas within the study area is presented in Figure 3. In the study area there was no save area of landslide. Table 5 presented the composition of the study area based on the landslide hazard classes.-1

\begin{tabular}{l|l|} 
andslides & $\begin{array}{c}\text { hazard classes.-1 } \\
\text { Density }\left(\mathrm{Ha}^{-1}\right)\end{array}$ \\
& The05umbers of landslides within ev-
\end{tabular}
ery landsbide hazard class as presented in the Table 5 showed that $44 \%$ of landslide occasions were situated in the low landslide hazard areas. 9 \&is was un-logical situation because most of landslide occasions must be situated in the high and or very high landslide hazard areas. The mapping process of the landslide hazard in the study area was done based on the $1: 25.000$ scale of base map. This base map had 12,5 m contour intervals. The landslide occasions occur in the low landslide hazard class were triggered by human activities that created steep slope with elevation differences less than $12,5 \mathrm{~m}$. Therefore, those situations were not able detected from the base map used in this research.

The areas of low landslide hazard occupied the alluvial plain and colluvial - 
Figure 2. The cracks on the nearby road constructions and river bank initiate the landslide in the low landslide hazard areas which can not be identified through the $1: 25.000$ scale of base map.

foot slope landform. Those landforms were situated narrowly along the main river in the study area. Within this area, the main road connecting the capital city of subsistrict with the capital city of district was located. Nearby areas of the main local road was recently become more occupied by houses having function both for business and/or living place.

The areas of moderate landslide hazard were situated on the hills and mountain foot slopes zone. Those areas were mostly used as enlargement of settlement 
Tabel 5. The Relation between Landslides Points and Landslide Hazard Classes

\begin{tabular}{|c|l|r|r|c|c|}
\hline \multirow{2}{*}{$\begin{array}{c}\text { Number of } \\
\text { Landform Unit }\end{array}$} & Hazard Classes & \multicolumn{2}{|c|}{ Area dimension } & \multicolumn{2}{c|}{ Landslide Points } \\
\cline { 3 - 6 } & Very Low & 0 & $\begin{array}{c}\text { Number of } \\
\text { Landslides }\end{array}$ & $\begin{array}{c}\text { Density } \\
\left(\mathrm{Ha}^{-1}\right)\end{array}$ \\
\hline 1 & Low & 1766.0 & 33.6 & 127 & 0 \\
\hline 2 & Moderate & 1418.0 & 27.0 & 56 & 0,039 \\
\hline 3 & High & 2035.6 & 38.7 & 108 & 0,054 \\
\hline 4 & Very High & 41.0 & 0.8 & 0 & 0 \\
\hline 5 & S u m & 5260.6 & 100 & 291 & - \\
\hline \multicolumn{2}{|c|}{} \\
\hline
\end{tabular}

Source: map analysis

purposes with accompanied facilities. The moderate landslide hazards classes were also located around the old settlement areas. The dry land agriculture and mix garden farm were typical landuse types in the area of moderate landslide hazard.

The high landslide hazard classes were situated on the hills-mountain of breccia with biggest proportion of large area compared with the other classes. The steep slope condition, the availability of common landuse such as mixed plantation and dry land farms combined with the soil characteristic and weathered rock which has high infiltration capacity was the major causing factors to the high class of the landslide hazard.

According to the data showed in Table 5, the landslides mostly happened in the area with low level of landslide hazard. Many landslides occurred in the narrow alluvial plain along the river. The area of alluvial plain was generally utilized as settlement and wet land agriculture such as paddy field. Sand and stone mining along the river had triggered the landslide pro- cesses. These landslides had given negative impact to the settlement and road infrastructure which directly cause many inhabitant killed and loss of property. At least 12 lost of life and 8 houses was completely destroyed by landslide during the year 2004 .

Many road sections were situated in the border area between alluvial plain and hills footslope. The cutting slope activities on the footslope which composed by landslide deposit had become a triggering factor along the road to the capital city of the Loano Sub-District.

The landslide density within the high landslide hazard class was approximately one landslide per 2 ha of land. This area was dominated by mixed garden and dry land agriculture land. Moreover, this area is not relatively disturbed compared with the plain area. Many landslides which happened within this area were considerably because of the natural factors.

The landslide occurrence during the study period was not recorded inside the very high landslide hazard area. This was 


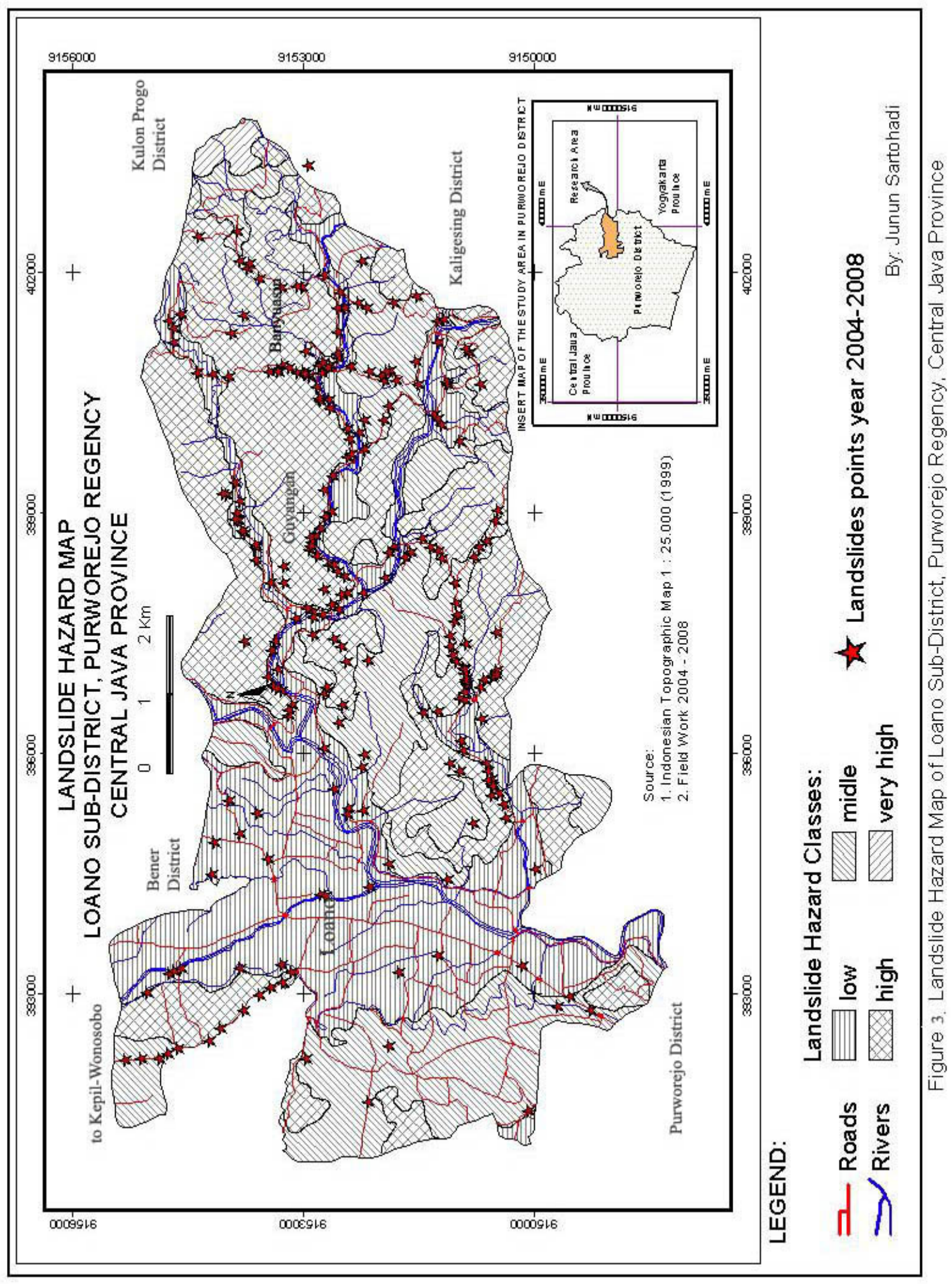


might be caused by the relatively limited acreage compared with the others. Another reason was that the soil in that area was relatively thin. Hence, the utilization of this soil was not so intensive and tends to be leaved in natural condition as a bushes land area.

\section{Road networks across the landslide hazard area}

There were 3 classes of road, i.e. local, provincial, and national. The local roads cover all the interconnection roads of villages and sub-villages that able for four wheels vehicles. The provincial road was the main road connecting the study area and Wonosobo District. The national road is the main road connecting Purworejo District and Magelang District. All of those roads across the study area having varied of landslide hazard classes as showed in the Tabel 6.

The landslide located around the road with the maximum distance $100 \mathrm{~m}$ were considered as landslide influenced by road construction. The influence of road construction could be in the form of slope cutting, ground vibration due to heavy vehicle movement, and runoff concentration along the road. The slope cutting was considered as slope steepening. As mentioned in the theory the slope steepening and ground vibration were two main factors controlling landslide processes. The slope cutting were often to cut the lithological contact between permeable and impermeable layers. The lithological contact would become seepage or spring water line along the road. During the raining time, this lithological contact could act as slickenside plane for landslide.

The highest density of landslide occurred in the provincial roads crossing the high landslide hazard area. The provincial road from the study area toward Kepil SubDistrict in Wonosobo was the climb-up road. The areas crossed by road were consisting deeply weathered old Sumbing Volcano materials. Slope cutting along the provincial road had created steep road side slope. Therefore, those situations had created some landslide occasions particularly during the rainy season.

The national road crossed mostly gentle slope within the study area. The national road only consisted of small distance road crossed hills foot slope. The landslide

Table 6. Road Network in the Study Area Related with Landslide Hazard Classes

\begin{tabular}{|c|c|c|c|c|c|c|c|c|c|}
\hline \multirow{2}{*}{$\begin{array}{l}\text { Hazard } \\
\text { Level }\end{array}$} & \multicolumn{3}{|c|}{ Provincial Road } & \multicolumn{3}{|c|}{ National Road } & \multicolumn{3}{|c|}{ Local Road } \\
\hline & $\begin{array}{c}\text { Length } \\
(\mathrm{Km})\end{array}$ & $\begin{array}{l}\text { Number of } \\
\text { Landslide }\end{array}$ & $\begin{array}{l}\text { Density } \\
\left(\mathrm{Km}^{-1}\right)\end{array}$ & $\begin{array}{c}\text { Length } \\
(\mathrm{Km})\end{array}$ & $\begin{array}{c}\text { Number of } \\
\text { Landslide }\end{array}$ & $\begin{array}{c}\text { Density } \\
\left(\mathrm{Km}^{-1}\right)\end{array}$ & $\begin{array}{c}\text { Length } \\
(\mathrm{Km})\end{array}$ & $\begin{array}{c}\text { Number of } \\
\text { Landslide }\end{array}$ & $\begin{array}{l}\text { Density } \\
\left(\mathrm{Km}^{-1}\right)\end{array}$ \\
\hline Low & 0.8 & 0 & 0.0 & 5.61 & 4 & 0.71 & 66.21 & 123 & 1.9 \\
\hline Moderate & 0.82 & 4 & 4.9 & 0.7 & 1 & 1.43 & 35.91 & 45 & 1.3 \\
\hline High & 1.49 & 8 & 5.4 & 0 & 0 & 0.00 & 21.1 & 95 & 4.5 \\
\hline Very High & 0 & 0 & 0.0 & 0 & 0 & 0.00 & 0.11 & 0 & 0.0 \\
\hline Total & 3.11 & 12 & - & 6.31 & 5 & - & 123.33 & 248 & - \\
\hline
\end{tabular}

Source: map analysis 
occasions were mostly located around the bridges. The canal where the bridge located usually become an outlet of some drainage canal around the road. Some of canal was too small and the stream was too strong during the raining time. Nevertheless, the stream were often eroding the area around the bridge and created small landslide. The ground vibration due to moving heavy vehicle also could act as another trigger factors for landslide around the national roads.

The highest density of landslides along the local road was located in the high landslide hazard area. Comparing the data presented in the Table 5 and Table 6 , most of the landslides were influenced by road construction. Only about $10 \%$ of the landslides were due to physical condition of the land.

High numbers of landslides were found along the local road crossing the low landslide hazard area. Most of the roads crossed the gentle slope located along the border line between footslope and alluvial plain. The small slope cutting in the hills and mountain foot slope had created higher hazard status of landslide. Moreover, the sand and stone mining in the river canal had created landslides along the river bank within the alluvial plain.

\section{CONCLUSIONS}

The conclusions of this research based on some point discussed in the previous parts could be formulated below:

1) there were 291 landslides during the research period started in January 2004 up to March 2008.

2) based on the geomorphological approach, the landslide hazard of the study area can be evaluated. The study area consisted of: low, moderate, high, and very high classes. There were no save area of landslide in the study area.

3) most the landslide occasions were more influenced by human activities than derived by physical conditions. Some of human activities that induced landslide in the study area were slope cutting for: road construction, houses, agricultural purposes, and sand and stone mining in the river canal.

4) the spatial distribution of most landslide $(>90 \%)$ were parallel with road networks.

\section{RECOMMENDATIONS}

Some recommendations related to the results of the research were formulated as follow:

1) to minimize the landslide along the roads, the slopes side of the road should be stabilized

2) river stream should be maintained in order to minimize under cutting processes due to river bank erosion; slope of river bank should be stabilized.

3) slope stabilization in the area surrounding of settlement is needed

4) community empowerment is necessary in order to improve people capacity to cope the landslide

5) further research in landslide hazard which strong consideration on impact of human activity is required. 


\section{ACKNOWLEDGEMENTS}

The author would like to express his deep gratitude to some of his colleagues: Mr. Danang Sri Hadmoko, MS. Ainun Harlin, Mr. Nugroho Christanto, Mr. Anggri Setiawan as well as Mr. Aris Marfai, MS.
Dyah Rahmawati and MS. Estuning Tyas who have shared their time during the field data collections. They also have given some improvement comments on the first draft of this paper. Great appreciation also extends to all of his students who have done many field works in Loano Sub-District.

\section{REFERENCES}

Alkema, D and Cavallin, (2001). Geomorphologic Risk Assessment for EIA. Studi Trontini, di Scienze Natureli, Acta Geologica, 78, 139-145.

Cornforth, D.H., 2004. Landslide in Practice: Investigations, Analysis, and Remedial/ Preventive Options in Soils. John Willey \& Sons, Inc., USA.

Dai FC, Lee CF, Ngai YY. (2002). Landslide Risk Assessment and Management: an overview. Engineering Geology, 64, 65-87.

Gunadi, S., Sartohadi, J, Hadmoko, D.S., Hardiatmo, H.C., and Giyarsih, S.R., 2004. Tingkat Bahaya Longsor di Kecamatan Samigaluh dan Daerah Sekitarnya, Kabupaten Kulonprogo, Propinsi Daerah Istimewa Yogyakarta: Prosiding Seminar Nasional Degradasi Hutan dan Lahan, Yogyakarta 10-11 Desember 2004.

Hadmoko, D.S., 2007. Toward GIS-based integrated landslide hazard assessment: a critical overview, Indonesian Journal of Geography, 34 (1), 55-77.

Hadmoko D.S, Lavigne F., 2007. Landslides in Menoreh Mountains, Central Java, Indonesia: dynamics, triggering, spatio-temporal analysis, and associated hazards. Paper presented on the International Conference of International Association of Geomorphologists on Environmental Change in the Tropic. Kota Kinabalu, Sabah, Malaysia 22-25 June.

ILC, 2004. International Landslide Centre. University of Durham. http://www.landslidecentre. org/database.htm. March 15th 2008

Korup, O (2003). Geomorphometric Characteristics of New Zealand Landslide Dams. Engineering Geology, 73, 13-35.

Kuhn, F.K., 1996. Basic Physics: A Self-Teaching Guide. John Willey \& Sons Inc. USA

Kuswaji Dwi Priyono, Yuli Priyana, dan Priyono. 2006. "Analisis Tingkat Bahaya Longsor Tanah di Kecamatan Banjarmangu Kabupaten Banjarnegara”. Forum Geografi, Vol. 20. No. 2. Desember 2006. Hlm. 175-189.

Marfai, M.A. (2007). Landslide Susceptibility Mapping of Middle Agri-River Basin, San Lorenzo Area, Southern Italy. Issues on Geomorphology and Environment. Eds: S.K.Basu \& Sunil Kr. De. Pp 48-54. ACB Publications, Kolkata India. 
Marfai, M.A., King, L., Singh, L.P., Mardiatno, D., Sartohadi, J., Hadmoko, D.S., Dewi., 2007. Natural hazards in Central Java Province, Indonesia: an overview, Environmental Geology DOI 10.1007/s00254-007-1169-9. http://www.springerlink.com/content/ 8u38826x8g716t40/. Marc 16th 200

Moeyersons J, Trefois Ph, Lavreau J, Alimesi D, Badriya I, Mitima B, Mundala M, Munganga D.O, Nahimana L (2004). A Geomorphological Assessment of Landslide Origin at Bukavu, Democratic Republic of The Congo. Engineering Geology, 72, 73-87.

Moon, V and Simpson CJ. (2002). Large-Scale Mass Wasting in Ancient Volcanic Materials. Engineering Geology, 64, 41-64.

Ritohardoyo, S. dan Priyono. 2005. "Perkembangan Permukiman dan Perubahan Daya Dukung Lingkungan Perdesaan Daerah Aliran Sungai Progo”. Forum Geografi, Vol. 19, No. 2, Desember 2005. Hlm 127-141.

Schaetzl, R., and S. Anderson, 2005. Soils: Genesis and Geomorphology. Cambridge University Press, UK.

Slaymaker, O., and T. Spencer, 1998. Physical Geography and Global Environmental Change. Longman Ltd., Edinburgh U.K.

Van Westen C.J., Rengers N, and Soeters R (2003). Use of Geomorphological Information in Indirect Landslide Susceptinility Assessment. Natural Haz̧ards, 30, 349-419. 